\title{
Correspondence
}

\section{The Shackleton Valley controversy continued}

\section{H. McG. Dunnett}

4 The Close, Eliot Vale, Blackheath, London SE3 OUR

Received December 1992

The July 1992 issue of Polar Record (28 (166): 229-232) introduced a controversy about the route taken by $\mathrm{Sir}$ Ernest Shackleton, Frank Worsley, and Tom Crean across South Georgia in May 1916 and, in particular, their final arrival point on the coast. Was it Stromness - as Shackleton thought, and as maintained by Geoffrey Hattersley-Smith, Duncan Carse, M.K. Burley, and R.T. Morgan-Grenville — or Husvik, a theory propounded by Michael J. Gilkes? The accurate location of 'Shackleton Valley' sparked off the debate.

As independent evidence, I would like to quote from a letter written by Noel Baker about a chair that he brought back to Dulwich College from the Antarctic many years ago. Dulwich was Shackleton's old school, which possesses, among other relics, his boat, James Caird, now fully rigged and restored. Mr Baker had a youthful ambition to visit the Antarctic, and in the 1950s he joined a whaling factory ship, based in South Georgia, as the only way to fulfil it. Later he became a whaling inspector under the Crown Agents and served one season each at Leith Harbour and Grytviken. I quote from his letter:

Leith Harbour was controlled by Salvesen of Leith, Scotland, who also used the old (but now non-operating) whaling station of Stromness as a repair centre and drydock: it was a few miles from Leith and reached only by ship (a pensioned-off whale catcher).

Knowing well the Shackleton story, I naturally was keen to see Stromness and made several visits while I was at Leith Harbour. The Manager's Villa (as it was called), in which Shackleton had been made so welcome after his remarkable struggle of a journey across the island in 1916, was still thoroughly intact, and was serving as mess for the small permanent staff there.

It was quite small (why did I never take a photo?) with a sitting room, as I recall, no more than about 14' by $14^{\prime}$ - after almost 30 years this is no more than a guess - sparsely furnished, but I remember a table and (I think) three large, solid wooden chairs.

Naturally I pictured Shackleton in one of them, and my questioning of old hands, one of them had served there for many years, confirmed that these chairs had been in place throughout their acquaintance, and probably throughout the life of the villa, while the longestserving of all had known the station since 1920--only four years after Shackleton. He was certain that the chairs were there in 1920. Now, since Shackleton spent several days in the villa, and since seating was limited, it is as certain as circumstantial evidence can be that he will have sat in one, and most probably in all three.

Knowing that Salvesen were likely to abandon whaling, and that both Leith Harbour and Stromness would be deserted, I was concerned that the historic villa with its contents might be left to decay. The least I could do would be to bring home some Shackleton relic to offer to his old school. I knew that James Caird was there. So, while at Grytviken (1961-1962), I signalled Salvesen for permission to take a chair. This was granted, and at the end of the season the chair was brought round by sea, from Stromness to Grytviken, where it sat in my room for a couple of weeks, while I sat in it until we sailed for home.

$\mathrm{Mr}$ Baker duly reached London and offered the chair to Dulwich, where, for the last 30 years, it has had a place of honour among the school's many possessions.

I have involved myself in this discussion because I was a boy at Dulwich when the stripped down James Caird all that was left of her - arrived in 1924. I was alerted to the discussion about Shackleton's route by Angus Erskine, when he visited Dulwich last summer, and it occurred to me that Mr Baker's story of the chair might throw new light on the subject. I sent Mr Baker copies of the relevant pages in Polar Record. He responded:

I am intrigued, though non-plussed by Gilkes' Stromness/Husvik theory, for it has never occurred to me, nor to any of my interested friends, to doubt that Shackleton returned to Stromness. Burley, and also Roger Morgan-Grenville, who led the Army party in 1986, retraced Shackleton's steps across the island fully, and without question homed in on Stromness Station....

Shackleton transposing the names, Stromness and Husvik, does not worry me, for I imagine that, before 1916, South Georgia was merely a port of call on his southward journey - he had no reason to acquire intimate knowledge of the island and its whaling stations. So, when he came to compile his 'memory map,' he switched the two places. He probably had it drawn to illustrate his lectures and his book South in 1919. Few of us could go for a day's climb in, say, an unknown and snow-covered part of Norway and, exhausted, remember every twist and turn in a 3000-feet descent, several years later.

Erskine and Carse refer to possible topographical changes. Thirty winters of ice and snow with summer thaws in that part of the world can do a great deal of damage.

As for the points made by Gilkes at the top of page 237: how substantial and substantiated are they? The vague reference to a Husvik whaler, the photograph of Shackleton and Sørlle at Husvik in 1914 and Worsley's mix-up of, to him, foreign names, is rather a feeble back-up to the argument. The next paragraph is pure 
surmise. Earlier, Gilkes suggests that Shackleton could not have met Sørlle at Stromness in May because there was no fishing there. During my own several years' association with South Georgia whaling, it was the regular custom to leave behind an over-wintering party, to care for machinery and general caretaking duties; therefore, the stations, whether operational or not, were never unoccupied. This could explain Sørlle's presence at Stromness. This would also explain the presence of a ship lying at the wharf - referred to by Shackleton - for the convenience of the over-wintering party, presumably, although I would have expected a catcher, rather than a sailing ship.

Finally, Shackleton seems to have had no doubt as to where he was. In chapter XI of South, he wrote: 'After breakfast Mr Sørlle took us round to Husvik in a motor launch.' All the Norwegian whalers, whom I met in South Georgia, accepted that Stromness was where Shackleton's party ended up, and the story seemed to be part of their folklore, passed down by people who knew him and witnessed his arrival. Morgan-Grenville has told me himself that, after crossing the König Glacier, it must have been a lot easier to have gone to Stromness than to Husvik.

It is possible that, sometime in the future, Sal vesen may be able to throw more light from contemporary sources. Any company, operating thousands of miles from headquarters, and particularly a shipping company, would almost certainly maintain a log of events, for the benefit of the directors at the headquarters and visiting officials. It will depend on how far back such records were preserved. There may even be records in Norway, whalers' reminiscences, for instance.

Editor's note: Shortly after the preceding letter was received, another communication was received about which whaling station Shackleton, Worsley, and Crean initially reached after their crossing of South Georgia in 1916. In November 1992, Michael Gilkes wrote to James Meiklejohn, the chairman of the Salvesen Ex-Whalers Club in Tønsberg, Norway, to see if Mr Meiklejohn knew of anyone in the whaling community who might be able to produce old documents relevant to the Shackleton Valley controversy. After being in contact with Sonja and Karl Jan Skontorp, MrMeiklejohn wrote to Polar Record in the affirmative. The following are excerpts from separate letters from Mr Meiklejohn and Mr Skontorp.

\section{A resolution to the Shackleton Valley controversy \\ James Meiklejohn}

Salvesen Ex-Whalers Club, Munkegaten 1, 3100

Tønsberg, Norway

\section{Karl Jan Skontorp}

Tønsberg, Norway

\section{Received January 1993}

Let me first introduce myself. James Meiklejohn, born in Edinburgh. Employed with Salvesen of Leith for 17 years.
Sailed with Floating Factory Southern Venturer, then served at Leith Harbour Whaling Station, with four years overwintering. Transferred from Leith to Tønsberg and served with Salvesen's agent. Founded my own company and celebrated 25th anniversary a few days ago. In 1984 founded Salvesen Ex-Whalers Club....

At the end of November last year I received a letter from Michael Gilkes.... I have been in touch with friends who still have contacts in the whaling fraternity, and I enclose the following documents: (1) An extract taken from a letter written by Søren Berntsen to his wife, dated 1 June 1916. This letter is in the possession of his youngest daughter, Sonja, now Mrs Skontorp. (2) A translation of this extract by Karl Jan Skontorp, Sonja's son.

I gave them both copies of Michael Gilkes' letter, together with the notes published in Polar Record, and I stressed the importance of the original letter. I told them that the contents would 'lay to rest' irrevocably any further discussions and that proof was essential. It is thus with great pleasure that I enclose a copy of the original letter together with slides of each page, which I received today from the Skontorp family.

$$
\text { - • • }
$$

My name is Karl Jan Skontorp. I have been contacted by Mr James Meiklejohn regarding the question, 'Did Shackleton come to Husvik or Strømnes when he crossed South Georgia?' My grandfather, Søren Berntsen, was Manager at Husvik in the years from 1907 to 1917. I have translated the following extract from a private letter from my grandfather to his wife, the contents of which will eliminate irrevocably any lingering doubts. The letter is dated 1 June 1916:

Shackleton, who left here in December 1914 on a South Pole Expedition, arrived on the west coast of Georgia from South Shetland in a small rowing boat, 12 days ago. He had lost his vessel in the Ice in October. Since then he and his crew had stayed on the Ice for several months. Finally sailed with the lifeboats and ended up on Elephant Island in South Shetland. From there Shackleton and 5 of his crew sailed here to Georgia and landed on the west coast. Shackleton and 2 of his men walked across the island and came down to Strømnes. They were so bearded that Sørle didn't recognize them until he identified himself. The day after he came here, Sørle sent Samson to the other side of the island and fetched the 3 men who had stayed behind in the boat. Now they have departed to Elephant Island in South Shetland to get the remaining 22 men. They took one of Restitution's vessels which was laid-up here. Thom has gone with them. Shackleton asked if he could accompany them....

They have been gone now for 9 days and I expect them back tomorrow. Hope they have rescued the 22 men who were left. It is unbelievable that anyone could survive in a small boat from South Shetland to here at this time of year. Shackleton and two of the others slept here the night before they went on the rescue expedition and I heard the two make an awful noise in their sleep - they thought that they were back at sea in the small boat. 